\title{
ТАТАРЫ РЯЗАНСКОЙ ОБЛАСТИ В ХХ ВЕКЕ: РАССЕЛЕНИЕ, ДИНАМИКА ЧИСЛЕННОСТИ, НАПРАВЛЕНИЯ МИГРАЦИЙ
}

\section{PЕНАТ ТЕМИРГАЛЕЕВ}

\begin{abstract}
В статье рассматриваются различные демографические и миграционные процессы в среде татар Рязанской области, состоящей из двух этнотерриториальных групп - касимовских татар и татармишарей. На основе анализа статистических данных, нарративных источников, а также данных, полученных в ходе работы с обобщенным банком данных (ОБД) «Мемориал», выявлена особая, главенствуюшая роль регионов Средней Азии, в особенности Узбекистана, в миграционных связях татар Рязанской области. Установлено, что как в отношении динамики (роста/убыли) численности населения в ареалах проживания, так и в отношении направленности миграционных потоков две основные этнотерриториальные группь татар Рязанской области - касимовские татары и татары-мишари - имеют четкие особенности, явно отличающие их друг от друга. Разработана оригинальная методика выявления направленности миграционных потоков на основе анализа ОБД «Мемориал», содержащей документы о безвозвратных потерях РККА в Великой Отечественной войне по критерию «место рождения - место призыва».
\end{abstract}

Ключевые слова: демография, касимовские татары, «Мемориал», миграции, Рязанская область, Средняя Азия, татары, татары-мишари.

\section{АКТУАЛЬНОСТЬ ИССЛЕДОВАНИЯ}

Центральный федеральный округ - самый моноэтничный в России. Согласно данным переписи 2010 г., доля русского населения в нем составляет 89,1\%. В отдельных его регионах, в частности в Белгородской, Воронежской, Ивановской, Костромской, Курской, Липецкой, Орловской, Смоленской и Ярославской областях, доля русских превышает 90\%, а в Брянской, Тамбовской и Тульской приближается к 95\%. Еще более явственно моноэтничность Центральной России проявляется при рассмотрении сельского населения: 92,5\% жителей сельской местности Центрального федерального округа являются русскими, в Брянской, Ивановской, Липецкой и Ярославской областях этот показатель превышает 94\%, в Курской и Тамбовской - 95\%, в Костромской области - приближается к 96\%.

РЕНАТ ФАРИТОВИч ТЕМИРГАЛЕЕВ (renattemirgaleev@yandex.ru), МОСКОВСКИЙ ГОСУДАРСТВЕННЫЙ УНИВЕРСИТЕТ ИМЕНИ М.В. ЛОМОНОСОВА, РОССИЯ.

СТАТЬЯ ПОСТУПИЛА В РЕДАКЦИЮ В ИЮНЕ 2016 Г. 
Вместе с тем, относительно малоизученными с социально-демографической точки зрения остаются исторически сложившиеся на территории Центральной России этнические анклавы. В первую очередь к таковым следует отнести тверских карел и татар Рязанской области (касимовских и татар-мишарей). При этом если тверские карелы (потомки переселенцев с Карельского перешейка XVI-XVII вв.) в действительности образуют анклав, удаленный от основной территории проживания карел (400-500 км) в русскоязычном окружении, то поселения татар на территории современной Рязанской области с этнографической точки зрения являются продолжением обширного ареала волго-уральских татар, в частности татарско-мишарского ареала, занимающего целый ряд смежных регионов правобережья Волги (Республика Мордовия, Пензенская, Нижегородская, Ульяновская области и др.).

Несмотря на то, что доля татар в общей численности населения Рязанской области крайне мала $(0,43 \%$ в 2010 г.) и даже ниже, чем в ряде других регионов Центрального экономического района (г. Москва - 1,3\%, Московская область - 0,79\%, Ивановская область - 0,63\%, Владимирская, Тульская области - по 0,5\%, Тверская область - 0,43\%), сушественным отличием татарского населения региона является повышенная доля сельского населения, что является косвенным свидетельством того, что данная территория относится к ареалу их исторического расселения. В отличие от соседних областей, ядро татарского населения которых составляют потомки относительно недавних приезжих (отходников, рабочих различных индустриальных предприятий), в Рязанской области почти половина татар (45,2\%) проживает в сельской местности. Еще в 1970 г. доля сельских жителей среди татар региона составляла 59\%, а в 1939 г. - 86,2\%, что выделяет область на фоне других субъектов Центральной России ${ }^{1}$ (таблица 1).

Таблица 1. Доля сельского населения среди татар по субъектам Центрального экономического района, 2010, \%

\begin{tabular}{l|c|l|r}
\hline Субъект РФ & Доля & Субъект РФ & Доля \\
\hline Белгородская обл. & 35,74 & г. Москва & 0 \\
Брянская обл. & 35,50 & Орловская обл. & 46,17 \\
Владимирская обл. & 16,88 & Рязанская обл. & 45,23 \\
Воронежская обл. & 41,44 & Смоленская обл. & 29,16 \\
Ивановская обл. & 12,46 & Тамбовская обл. & 54,89 \\
Калужская обл. & 26,46 & Тверская обл. & 24,70 \\
Костромская обл. & 17,09 & Тульская обл. & 20,78 \\
Курская обл. & 32,29 & Ярославская обл. & 13,07 \\
Липецкая обл. & 40,87 & Всего по ЦФО/без учета Москвы & $9,94 / 22,62$ \\
Московская обл. & 18,37 & Всего по России & 32,28 \\
\hline
\end{tabular}

Источник: [Переписи населения... 2016].

Таким образом, сельское татарское население Рязанской области представляет собой в определенной степени уникальный феномен традиционного этнического анклава в моноэтничной Центральной России. В этой связи особенно важным представляется

\footnotetext{
1 За исключением Тамбовской и Орловской областей. В Тамбовской области, также входящей в исторический ареал расселения татар-мишарей, существуют два крупных татарских села - Татарщино и Энгуразово - с суммарным населением 856 чел. (2010 г.). Татарское население Орловской области составляет всего 1239 человек $(0,16 \%)$ и изучено недостаточно хорошо, но скорее всего, в значительной степени оно сформировалось в последние десятилетия ХХ в.
} 
изучение татарского населения Рязанской области с социально-демографической точки зрения.

\section{ПОСТАНОВКА ИССЛЕДОВАТЕЛЬСКОЙ ЗАДАЧИ}

Цель настоящего исследования - выявить закономерности в изменении общей численности татарского населения Рязанской области, доли татар в общей численности населения региона, доли городского и сельского населения в общей численности татар области, выявить направления миграционных потоков, по возможности определить причины миграционных волн и их хронологические рамки, а также составить целостный демографический портрет современного татарского населения Рязанской области, очертить основные тенденции и закономерности.

Объект настоящего исследования - татарское население Рязанской области, в этнографическом отношении состоящее из представителей двух субэтносов с четкой географической локализацией: касимовских татар и татар-мишарей.

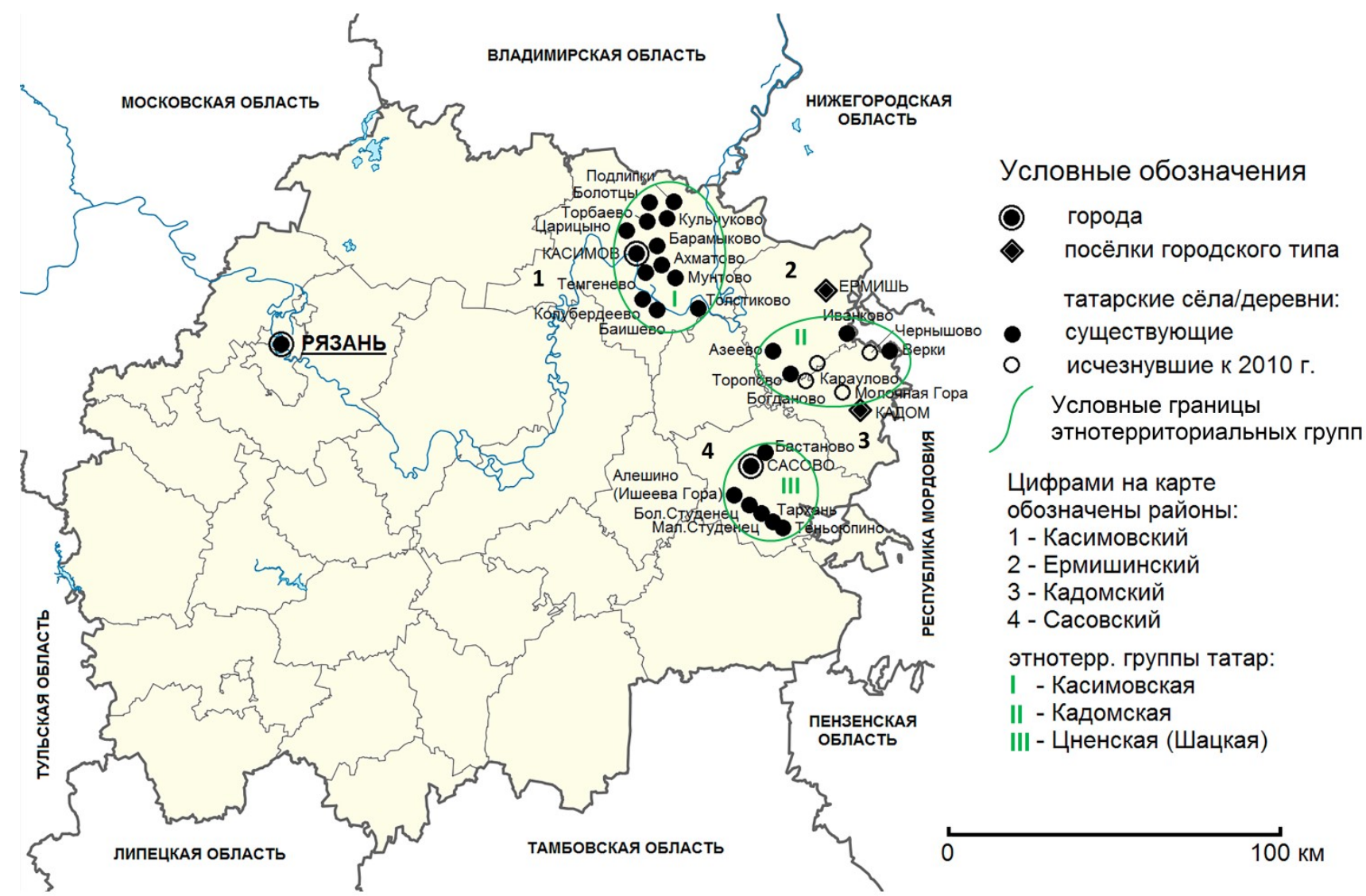

Рисунок 1. Татарские села Рязанской области

Источник: Составлено автором по [Этнотерриториальные группы ... 2002: 100; Ислам... 2009: 293, Шарифуллина 2004: 122].

Примечание: Указаны села с полностью или частично татарским населением. Полностью исчезнувшие или утратившие татарское население к 2010 г. села Касимовского района не обозначень в силу многочисленности. Границы этнотерриториальных групп показаны условно. 
Касимовские татары проживают на территории города Касимов и в Касимовском районе области, ранние этапы их этнической истории связаны с Касимовским ханством, существовавшим в западной части Мещеры в середине XV - конце XVII вв.

Татары-мишари на территории Рязанской области проживают в основном в сельских населенных пунктах Сасовского, Ермишинского и Кадомского районов ${ }^{2}$. В отличие от компактной группы касимовских татар их поселения являются составной частью обширного ареала расселения татар-мишарей, сложившегося в общих чертах к концу XVIII в. и включающего территории современных Нижегородской, Пензенской, Ульяновской областей, Республики Мордовия, ряда районов смежных областей, а также Самарскую, Оренбургскую области, республики Татарстан и Башкортостан, где татары-мишари живут бок о бок с представителями субэтноса казанских татар. На крайнем западе ареал современного сельского расселения татар-мишарей доходит до Тамбовской области, где сохранилось 2 татарских села: Татарщино (тат. Күршә) в Рассказовском районе и Энгуразово (тат. Яңгураз) в Уваровском районе. Междуречье Цны и Мокши на стыке Рязанской области и Республики Мордовия - ядро первоначальной территории расселения предков татар-мишарей, откуда началось их расселение в XVI-XIX вв. по регионам правои левобережья Волги, Приуралья и Зауралья, связанное на первых этапах преимущественно со строительством засечных черт на вновь присоединенных к русскому государству лесостепных и степных территориях, а позднее - с вольной колонизацией новых земель в связи с малоземельем в местах первоначального проживания и другими экономическими причинами [Мухамедова 1972: 18-27].

С точки зрения локализации татарское сельское население Рязанской области можно разбить на три относительно крупных «куста»: Касимовский, Цненский (Шацкий) и Кадомский (рисунок 1). Непосредственными соседями рязанских татар являются татары Мордовии, в частности темниковские татары-мишари, проживающие в сельских населенных пунктах Темниковского, Теньгушевского и ряда смежных районов республики. Следует отметить, что ранее населенные пункты темниковских татар, наряду с кадомскими и цненскими татарами, входили в состав Тамбовской губернии и сегодня отдельные села Теньгушевского района (напр., Атенино) фактически являются продолжением кадомского «куста», будучи отделенными от него лишь административной границей.

\section{ИЗУЧЕННОСТЬ ТЕМЫ}

Татарское население Рязанской области неоднократно становилось объектом научных исследований. Ряд работ так или иначе касался и демографии. Ф.Л. Шарифуллина еще в начале 1990-х годов издала монографию о касимовских татарах, переизданную с дополнениями в 2004 г. [Шарифуллина 2004]. Являясь преимущественно этнографическим исследованием, работа в значительной степени затрагивает и демографические аспекты.

\footnotetext{
2 Д.М. Исхаков относит татарское население территорий, прилегающих к Касимовскому уезду, также к касимовским татарам, отмечая, однако, их переходное положение между двумя субэтносами (татар-мишарей и касимовских татар) и условность их отнесения ко второму из них [Этнотерриториальные группы... 2002: 102-110].
} 
Так, автор приводит данные о численности татарского населения прилегающих к г. Касимов территорий, дает объяснение причинам его депопуляции, обозначает основные направления и причины миграций касимовских татар и, что, пожалуй, самое важное, приводит полный перечень населенных пунктов касимовских татар в конце XIX - начале XX вв. В монографии Р.Г. Мухамедовой [1972] в рамках изучения этнологии, истории и географии расселения татар-мишарей правобережья Волги и бассейна Оки дается подробный вариант выделения подразделений татар-мишарей по этнографическому и территориальному признаку. Вместе с тем рязанским мишарям в ней не уделяется много внимания. Д.М. Исхаков [1993] в рамках исследований этнотерриториальных групп татар, легших впоследствии в основу второго раздела комплексной монографии [Этнотерриториальные группы... 2002], уделяет большое внимание татарам Рязанской области, описывая их положение в структуре этноса волго-уральских татар и внутреннюю структуру. Фактически в монографии им уделен целый параграф. Однако, опять же в силу этнографической направленности работы, вопросам миграций, особенно XX в., в работе уделяется мало внимания. Следует выделить статьи М.А. Сафарова по истории и этнографии татар Рязанской области, в частности, вошедшие в энциклопедический словарь [Ислам... 2009], в которых подробно описывается история практически всех татарских населенных пунктов региона. М.А. Сафаров составил перечень татарско-мишарских сел области, а также на основе преимущественно нарративного материала обозначил тенденции миграционных связей татар региона со Средней Азией, Москвой и рядом других промышленных центров и регионов. Нельзя не упомянуть очень подробные исследования мусульманских общин Центральной России, произведенные Д.В. Макаровым и обобщенные им в монографии [Макаров 2012] и в уже упоминавшемся энциклопедическом словаре [Ислам... 2009]. Из наиболее значительных краеведческих работ следует отметить вышедшее в 2015 г. комплексное историко-краеведческое исследование «Очерки по истории и культуре села Бастаново» [Девликамов, Шарифуллина 2015].

Следует отметить, что безусловно хорошо проработанными, с научной точки зрения, в рамках обозначенной темы являются общие направления расселения и миграции татармишарей в XVI-XIX вв. В общих чертах обозначены и направления их миграций в XX в., однако базируются они в основном на отдельных сообщениях информаторов и нарративном материале. Вместе с тем до сих пор не было проведено комплексного научного исследования демографической истории, а также особенностей миграционных потоков татар Рязанской области, их направлений, временных рамок, причин и последствий с сугубо статистической точки зрения с опорой на количественные данные.

\section{ДЕМОГРАФИЧЕСКИЕ ТЕНДЕНЦИИ В СРЕДЕ РЯЗАНСКИХ ТАТАР В СЕРЕДИНЕ ХVIII - НАЧАЛЕ ХХ В.}

До 1923-1924 гг. значительная часть территории современной Рязанской области, в том числе районы компактного проживания татар, входила в состав Тамбовской губернии. В административном отношении они входили в состав Елатомского и Шацкого уездов. Оставшаяся часть татар нынешней Рязанской губернии по дореволюционному административно-территорилаьному делению проживала в Касимовском уезде Рязанской 
губернии. Сохранились данные по численности татарского населения различных уездов указанных губерний за разные годы с 1762 по 1857 г., приуроченные к III, IV, V, VIII и X ревизиям податного населения Российской империи (таблица 2).

Таблица 2. Численность татарского населения по уездам Тамбовской и Рязанской губерний с 1762 по 1897 г., человек

\begin{tabular}{l|r|r|r|r|r|rr}
\hline Губерния/уезд & 1762 г. & 1782 г. & 1795 г. & 1833 г. & 1857 г. & 1897 г. \\
\hline Тамбовская & 5616 & 6393 & 7484 & 10740 & 13152 & 16976 \\
Темниковский & 3930 & 4612 & 3278 & 4394 & 5753 & 5901 \\
Елатомский & 351 & 404 & 2557 & 4034 & 4157 & 5919 \\
Спасский & 816 & 858 & 875 & 1053 & 1355 & 2201 \\
Тамбовский & 260 & 234 & 395 & 681 & 806 & 1176 \\
Шацкий & 259 & 285 & 379 & 578 & 867 & 1026 \\
Прочие & - & - & - & - & 214 & 753 \\
Рязанская & 4265 & 4807 & 5999 & 5591 & 5656 & 5033 \\
Касимовский & 4265 & 4807 & 5999 & 5591 & 5647 & 4764 \\
Прочие & - & - & - & - & 12 & 146 \\
\hline
\end{tabular}

Источник: [Tатары 2001: 156].

За столетие с 1762 по 1857 г. татарское население всей Тамбовской губернии выросло почти в 2,5 раза (с 5,6 до 13,2 тыс. человек). Темпы роста численности татар соседней Рязанской губернии, представленных почти исключительно касимовской группой, в этот же период были на порядок меньше: она выросла лишь в 1,2 раза (с 4,3 до 5 тыс. человек). На наш взгляд, это в значительной мере объясняется более активными ассимиляционными процессами в среде касимовских татар, деятельностью православных миссионеров, в целом более низкими темпами естественного прироста в традиционно связанных с городской средой, торговлей, отхожими промыслами и городским образом жизни семьями касимовских татар. Своего пика численности (6,0 тыс. человек) татарское население Касимовского уезда достигло в 1795 г., после чего к 1833 г. снизилось до 5,6 тыс. Незначительный рост с 1833 по 1857 г. не оказывает влияния на общую тенденцию: к 1897 г. численность татар Касимовского уезда снизилось до 4,7 тыс. человек. При этом суммарно татарское население Елатомского и Шацкого уездов (ныне татарские села данных уездов входят в состав Рязанской области) с 1762 по 1857 г. выросло в 8,2 раза (!) с 0,6 до 5,0 тыс. человек. Столь серьезные диспропорции темпов роста, на наш взгляд, свидетельствуют о том, что в среде сельского татарского населения на территории современной Рязанской области еще в XVIII-XIX вв. существовали серьезные различия, оно было в значительной степени неоднородным, дифференцированным в территориальном и этнотерриториальном плане.

Депопуляция касимовских татар подтверждается научными исследованиями в смежных дисциплинах. Так, Ф.Л. Шарифуллина в своей монографии «Касимовские татары» [Шарифуллина 2004], углубляясь в этнодемографические процессы вплоть до упразднения Касимовского ханства в 1681 г., пишет: «С упразднением царства, которое являлось для татар своего рода этносоциальным организмом, были ликвидированы все те условия, на которых зиждилось сословие служилых татар. Прекратился приток извне тюркоязычного населения. Более того, среди касимовцев, как, впрочем, и у других групп поволжских татар, наблюдалось усиление миграционных процессов, что отразилось и на динамике их численности. Так, между 1719 и 1745 гг. происходит убыль татарского 
населения Касимовского уезда на 18\%. ... К концу XIX - началу XX вв. стало заметным снижение численности татар в Касимовском районе. Они устремлялись в поисках средств существования в различные области страны. Часть их (около 15\%) оседала на постоянное жительство в различных городах. Например, в начале XX в. зафиксирован приток касимовцев в Петербург. Встречались факты переселения небольших групп населения (возможно, ремесленников и торговцев) и в сельские районы Среднего Поволжья и Приуралья...». Она же, составив список сельских поселений касимовских татар, отмечает, что некоторые из 38 перечисленных в нем сел уже в конце XIX - начале XX в. не имели татарского населения.

Исследователь мусульманских общин Центральной России Д.В. Макаров пишет: «Во 2-й половине XIX в. в регионе развернулась активная деятельность по крещению касимовских татар, центрами которой были Миссионерское общество в Касимове и православные учреждения в татарской деревне Карамышево. Есть основания полагать, что отдельные группы касимовских татар, проживавших в Касимове и на селе, в тот период приняли крещение и впоследствии обрусели» [Макаров 2012].

Из прочих явлений и тенденций в численности населения татар Тамбовской и Рязанской губерний с 1762 по 1857 г. можно выделить бурный рост численности татар Елатомского уезда. Если татарское население соседнего Темниковского уезда (ныне по большей части - в составе Республики Мордовия), изначально превосходившее татарское население Елатомского уезда в 11 раз, выросло за 100 лет всего в 1,5 раза (с 3,9 до 5,6 тыс. человек), то татары Елатомского уезда увеличили свою численность в 11,8 раз (!) с 0,35 до 4,2 тыс. человек. В состав Елатомского уезда входили 4 татарско-мишарских села: Азеево, Бастаново, Торопово и Богданово (первые два относятся к числу крупнейших в регионе), а также несколько сел касимовских татар вблизи границы с Касимовским уездом (Толстиково, Шилино, Высоково, возможно, ряд других, более малочисленных). Согласно «спискам населенных мест» Тамбовской губернии за 1862 г. в трех последних указанных селах (с хуторами) проживало суммарно 690 человек. В 1857 г. общее татарское население Елатомского уезда составляло 4157 человек, соответственно, большая часть роста численности пришлась именно на татарско-мишарские села уезда. Если в 1762 г. Темниковский уезд явно выделялся на фоне соседей большой численностью татар, то к концу XIX в. Елатомский уезд при изначально совсем небольшой численности татар сначала сравнялся, а затем и обошел его по данному показателю.

Исходя из представленных в таблице 2 данных, можно приблизительно рассчитать численность татарского населения в пределах современной Рязанской области. Для этого автор прибег к простому сложению численности татар Елатомского, Шацкого уездов Тамбовской губернии и Касимовского уезда Рязанской губернии. Частично (по расчетам автора - порядка $10 \%$ от численности) к нынешней Рязанской области относились и некоторые татарские села Темниковского уезда. Принимая во внимание этот факт, можно приблизительно оценить численность рязанских татар в 1762 г. в 4,8-5,2 тыс. человек, а в 1857 г. - в 10,6-11,2 тыс. человек. Применяя эту же методику к цифрам первой всероссийской переписи населения 1897 г., численность татар в пределах современной Рязанской области можно оценить в 11,7-12,3 тыс. человек. 
Подводя промежуточный итог, можно сделать вывод, что к рубежу XIX-XX вв. при общем устойчивом росте численности татарского населения современной Рязанской области наблюдались территориальные диспропорции: стабильная депопуляция касимовских татар, бурный рост численности татарского населения Шацкого и особенно Елатомского уездов. Подавляющая часть роста пришлась на татарско-мишарские населенные пункты региона.

\section{ДЕМОГРАФИЧЕСКИЕ ТЕНДЕНЦИИ В СРЕДЕ РЯЗАНСКИХ ТАТАР ПОСЛЕ}

\section{7 Г.}

Согласно первой всеобщей переписи населения СССР 1926 г. татар на территории Рязанской губернии (не совпадавшей границами с территорией современной Рязанской области, но включившей в свой состав все ныне находящиеся на ее территории татарские поселения) насчитывалось около 10,7 тыс. человек, что составляло $0,44 \%$ от общей численности населения губернии.

Собственно Рязанская область была образована 26.09.1937, до 1954 г. она включала в свой состав ряд районов нынешней Липецкой области, доля татар в населении которых стремится к нулю. Первая перепись населения в этих границах прошла в 1939 г. По ней на территории региона проживало 8,6 тыс. татар или $0,38 \%$ от общей численности населения $\left(0,44 \%\right.$ без учета районов, отошедших в 1954 г. к Липецкой области $\left.{ }^{3}\right)$. Вне зависимости от достоверности этих данных и корректности их сравнения с данными по Рязанской губернии 1926 г. следует признать факт убыли татарского населения области впервые за историю наблюдений. Именно в период с середины 1920-х до конца 1930-х годов произошло множество социальных потрясений, до основания перевернувших традиционный сельский уклад жизни. Наиболее серьезными из них следует признать «чрезвычайные меры» в деревне конца 1920-х годов, коллективизацию 1929-1933 гг., голод, эпидемии, а также продолжающиеся преследования по религиозному признаку в условиях, когда религия в иноэтничном окружении является важнейшим консолидирующим фактором, препятствующим ассимиляции. Все эти факторы, на наш взгляд, привели к тому, что в указанный период татарское население Рязанской области начало резко убывать (таблица 3), при этом наиболее важными факторами здесь явились ассимиляция и выезд на постоянное место жительства в другие регионы страны. О направлениях миграционных потоков рязанских татар подробнее будет сказано далее.

С 1939 по 1959 г. татарское население Рязанской области сократилось в 2 раза (с 8,6 до 4,3 тыс. человек). Несмотря на то, что значительная доля демографических потерь в данные годы вызваны Великой Отечественной войной, стоит отметить, что темпы убыли татар в этот период значительно превышали темпы убыли населения региона в целом (сокращение на $25 \%$ - с $1,93^{4}$ до 1,44 млн человек), что, на взгляд автора, убедительно

\footnotetext{
3 Воскресенский, Данковский, Добровский, Лебедянский, Лев-Толстовский, Октябрьский (Березовский), Троекуровский, Трубетчинский, Раненбургский районы с общей численностью населения 342792 чел. в 1939 г. [Переписи населения... 2016].

${ }^{4}$ Без учета районов, отошедших в 1954 г. к Липецкой области. 
свидетельствует о продолжении ассимиляционных и миграционных процессов в среде татар области.

Таблица 3. Численность татар Рязанской области и их доля в общем населении региона, 1926-2010

\begin{tabular}{l|c|c|c}
\hline Год & Все население, тыс. чел. & Татары, тыс. чел. & Татары, \% \\
\hline 1926 г. & 2428,9 & 10,7 & 0,44 \\
1939 г. & 1925,1 & 8,6 & 0,44 \\
1959 г. & 1444,8 & 4,3 & 0,30 \\
1970 г. & 1411,6 & 4,1 & 0,29 \\
1979 г. & 1365,8 & 4,3 & 0,32 \\
1989 г. & 1347,8 & 4,9 & 0,37 \\
2002 г. & 1227,9 & 5,6 & 0,45 \\
2010 г. & 1154,1 & 4,9 & 0,43 \\
\hline
\end{tabular}

Источник: [Переписи населения... 2016].

Примечание: 1926 г. - данные по губернии, 1939 г. - без районов, отошедших в 1954 г. к Липеикой области.

Период с 1959 по 1970 г. характеризуется некоторой стабилизацией численности как всего населения региона, так и татарской его части. Вместе с тем и в этот относительно стабильный период численность татар падала быстрее: убыль в 6,4\% против 2,3\% по общей численности населения Рязанской области. Примечательно, что 1970 г. ознаменован историческим минимумом доли татар в общей численности населения региона $(0,29 \%)$.

С этого же года начинается следующий этап демографической истории татар Рязанской области: с 1970 по 2002 г. татарское население региона демонстрирует устойчивый рост (37,3\% за указанный период) при падении общей численности населения области в эти же года на 13\%. При этом за три десятилетия татарское население региона росло неравномерно. С 1970 по 1979 г. оно выросло на 6,6\%, с 1979 по 1989 г. - на 13,8\%, а с 1989 по 2002 г. - на 13,1\%. В этой связи можно сказать, что демографические тенденции в среде татар Рязанской области, наконец, сблизились с общей канвой роста татарского населения РСФСР/РФ. В указанный период 1970-2002 гг. татарское население России в целом выросло на 16,8\%. Татарское население России росло во все периоды с 1926 по 2002 г., рост численности рязанских татар начался лишь с 1970 г. и ускорился в 19792002 гг. Например, в целом по России с 1989 по 2002 г. татарское население выросло на 0,6\%, в то время как татарское население Рязанской области - на 13,1\% (рисунок 2). Таким образом, причины относительно быстрого роста численности татар рассматриваемого региона, по мнению автора, лишь в незначительной степени связаны с естественным приростом. Главной же причиной в данном случае является некий внешний приток, напрямую связанный с реиммиграционными процессами, в частности возвращением в родные села значительной части татар, выехавших в 1920-е - 1930-е годы в регионы Средней Азии, спасаясь от раскулачивания и голода. Начавшись в 1970-е годы, реиммиграция набрала силу к рубежу 1980-х - 1990-х годов в связи с дезинтеграционными процессами и нестабильностью в регионах Средней Азии. О подтверждении гипотезы о преобладании именно этого региона в миграционных потоках рязанских татар будет сказано далее. 

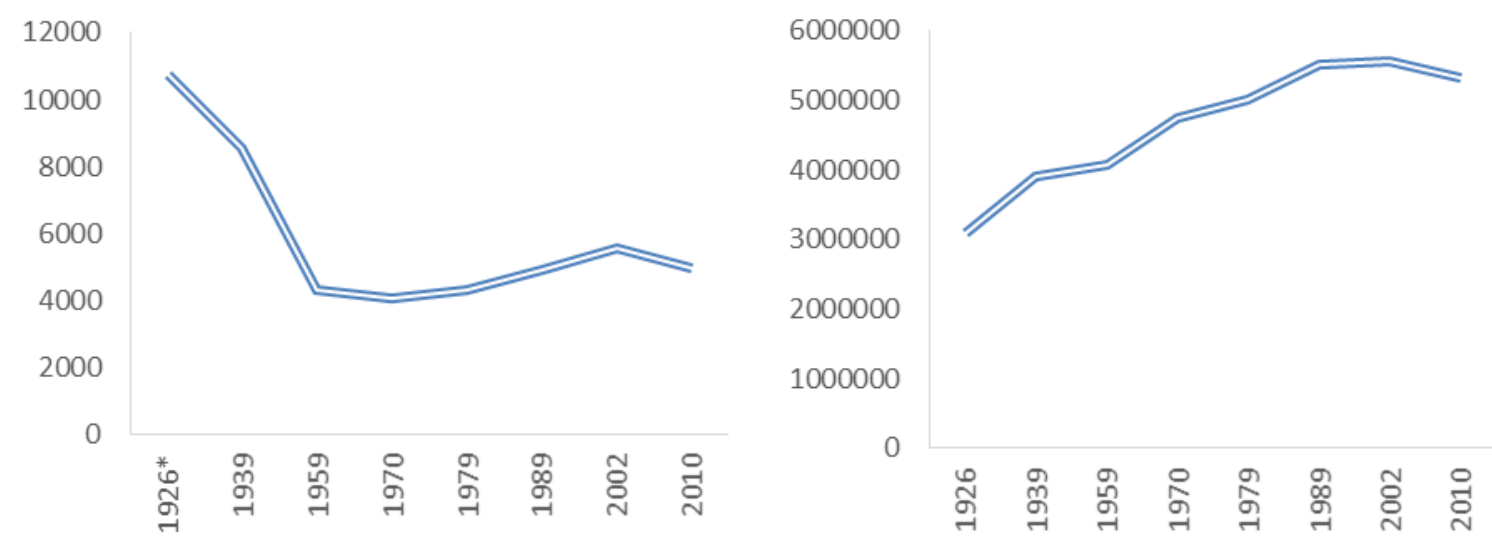

Рисунок 2. Численность татар Рязанской области (слева) и РСФСР/РФ (справа)

Источник: Расчеты автора по [Переписи населения... 2016].

Примечание: * - Данные по губернии.

В 2002-2010 гг. вновь наблюдается убыль численности татар Рязанской области с 5,6 до 4,9 тыс. человек (-11,3\%). При этом убыль рязанских татар в этот период явно выделяется как на фоне убыли численности населения региона в целом $(-6,0 \%)$, так и на фоне убыли татарского населения во всей Российской Федерации (-4,4\%). Судя по всему, в этот период произошло исчерпание реиммиграционного потока, подпитывавшего татарские села региона в предыдущие десятилетия и в силу вновь вступили факторы естественной убыли.

\section{ДЕМОГРАФИЧЕСКИЕ И СОЦИАЛЬНО-ЭКОНОМИЧЕСКИЕ ОСОБЕННОСТИ ТАТАР РЯЗАНСКОЙ ОБЛАСТИ В СРАВНЕНИИ С ТАТАРСКИМ НАСЕЛЕНИЕМ СОСЕДНИХ РЕГИОНОВ И РОССИИ В ЦЕЛОМ}

Характерной отличительной чертой татар Рязанской области является низкий уровень урбанизации (таблица 4). Согласно переписи населения 2010 г. в городах проживало лишь $54,8 \%$ татарского населения региона, что значительно ниже показателя как в целом по области (70,9\%), так и в целом по татарскому населению России $(67,7 \%)$. Порог 50\% рязанские татары впервые преодолели лишь в 1979 г. с отставанием от показателя в целом по региону почти на 10 лет. Вместе с тем при оценке урбанизированности татар Рязанской области следует иметь в виду, что значительная часть уроженцев татарских сел региона уезжали на заработки или на постоянное место жительства не в города соответствующего субъекта, а в Москву, Ленинград, Казань и прочие крупные города других регионов.

Интересные результаты показывает сравнение динамики роста/убыли татарского населения Рязанской области с некоторыми соседними регионами (таблица 5).

Татары Нижегородской области (образующие особую компактную этнотерриториальную группу на юго-востоке региона в Сергачском, Пильнинском, Краснооктябрьском районах) в период с 1939 по 1959 г. снизили численность на 24,08\% (в целом по региону -7,21\%), с 1959 по 1970 г. наблюдался рост численности татар региона на 7,16\% (в целом по региону +0,79\%). Далее в период 1970-2002 гг. наблюдалось неуклонное 
снижение численности татар области на 29,5\%. В 2002-2010 гг. данная тенденция убыли продолжилась. Стабильное снижение численности и доли (с 2,28\% в 1939 г. до 1,33\% в 2010 г.) татар Нижегородской области связано преимущественно с массовым исходом населения в города, в частности в Москву, с которой у татар данного региона существуют устойчивые миграционные связи. Реиммиграционного потока, обусловившего некоторый рост численности и доли татар в 1970-2002 гг., как в случае татар Рязанской области, в Нижегородской области не было. Что касается показателя урбанизированности, имеются значительные сходства: в 2010 г. лишь 56,1\% татар Нижегородской области проживали в городах, что значительно ниже как показателей в целом по региону, так и в среднем по татарам РФ.

Таблица 4. Доля горожан среди татар Рязанской области и в общей численности населения региона, 1926-2010, \%

\begin{tabular}{|c|c|c|}
\hline Год & Доля горожан среди татар & Доля горожан в общем по области \\
\hline 1926 & 6,57 & 8,00 \\
\hline 1939 & 13,71 & 9,72 \\
\hline 1959 & 30,18 & 29,94 \\
\hline 1970 & 40,86 & 47,09 \\
\hline 1979 & 50,69 & 57,47 \\
\hline 1989 & 54,39 & 65,00 \\
\hline 2010 & 54,77 & 70,91 \\
\hline
\end{tabular}

Источник: [Переписи населения... 2016].

Примечание: 1926 г. - данные по губернии.

Таблица 5. Численность татар ряда соседних с Рязанской областью субъектов и РСФСР/РФ в целом и их доля в общем населении регионов, 1926-2010

\begin{tabular}{|c|c|c|c|c|c|c|c|c|}
\hline Год & $\begin{array}{c}\text { Все } \\
\text { население, } \\
\text { тыс. чел. }\end{array}$ & $\begin{array}{c}\text { В том числе } \\
\text { татар, тыс. } \\
\text { чел. }\end{array}$ & $\begin{array}{c}\text { Татары, } \\
\%\end{array}$ & $\begin{array}{c}\text { Горожан } \\
\text { среди } \\
\text { татар, \% }\end{array}$ & $\begin{array}{c}\text { Все } \\
\text { население, } \\
\text { тыс. чел. }\end{array}$ & $\begin{array}{c}\text { В том числе } \\
\text { татар, тыс. чел. }\end{array}$ & $\begin{array}{c}\text { Татары, } \\
\%\end{array}$ & $\begin{array}{c}\text { Горожан } \\
\text { среди } \\
\text { татар, \% }\end{array}$ \\
\hline & \multicolumn{4}{|c|}{ Нижегородская область } & \multicolumn{4}{|c|}{ Республика Мордовия } \\
\hline 1926 & н.д. & н.д. & н.д. & н.д. & н.д. & н.д. & н.д. & н.д. \\
\hline 1939 & 3869,9 & 88,2 & 2,28 & 14,52 & 1188,0 & 47,4 & 3,99 & 2,65 \\
\hline 1959 & 3590,8 & 67,0 & 1,87 & 34,61 & 1000,2 & 38,6 & 3,86 & 15,05 \\
\hline 1970 & 3682,5 & 71,8 & 1,95 & 39,44 & 1029,6 & 45,0 & 4,37 & 24,64 \\
\hline 1979 & 3711,6 & 68,6 & 1,85 & 44,74 & 989,5 & 45,8 & 4,63 & 32,57 \\
\hline 1989 & 3719,6 & 58,6 & 1,58 & 52,30 & 963,5 & 47,3 & 4,91 & 44,42 \\
\hline 2002 & 3524,0 & 50,7 & 1,44 & н.д. & 888,8 & 46,3 & 5,21 & н.д. \\
\hline 2010 & 3310,6 & 44,1 & 1,33 & 56,09 & 834,8 & 43,4 & 5,20 & 46,42 \\
\hline & \multicolumn{4}{|c|}{ Пензенская область } & \multicolumn{4}{|c|}{ РСФСР/РФ } \\
\hline 1926 & н.д. & н.д. & н.д. & н.д. & 100891,2 & 3089,3 & 3,06 & 12,90 \\
\hline 1939 & 1710,5 & 64,7 & 3,78 & 4,87 & 108377,0 & 3683,0 & 3,40 & 22,00 \\
\hline 1959 & 1509,6 & 62,2 & 4,12 & 10,79 & 117534,3 & 4074,3 & 3,47 & 42,15 \\
\hline 1970 & 1536,0 & 74,8 & 4,87 & 15,58 & 130079,2 & 4755,1 & 3,66 & 49,68 \\
\hline 1979 & 1510,3 & 78,2 & 5,18 & 21,22 & 137409,9 & 5005,8 & 3,64 & 58,28 \\
\hline 1989 & 1504,6 & 81,3 & 5,40 & 29,13 & 147021,9 & 5522,1 & 3,76 & 65,79 \\
\hline 2002 & 1452,9 & 86,8 & 5,97 & н.д. & 145166,7 & 5554,6 & 3,83 & н.д. \\
\hline 2010 & 1386,2 & 86,4 & 6,24 & 36,99 & 142856,5 & 5310,6 & 3,72 & 67,72 \\
\hline
\end{tabular}

Источник: [Переписи населения... 2016].

Татарское население соседней с Рязанской областью Мордовии в интересующий нас период с 1970 по 2002 г. оставалось практически неизменным (рост 2,9\%). Следует отметить в целом очень высокую стабильность численности татар Мордовии (47,3 тыс. в 1939 г., 43,4 тыс. в 2010 г.), что на фоне падения численности республики в целом 
оборачивается неуклонным ростом удельного веса. Что касается уровня урбанизации, то татарское население Мордовии в этом отношении схоже с татарским населением Рязанской области и даже превосходит в его в доле селян: лишь 46,4\% татар региона живут в городах, что выделяется даже на фоне слабо урбанизированной Республики Мордовия в целом (60,4\% горожан).

В Пензенской области татарское население, хотя и росло в период с 1970 по 2002 г., темпы роста (16,0\%) были даже ниже показателей за одно предыдущее десятилетие 1959 1970 гг. (20,3\%). С 2002 по 2010 г. татарское население региона практически не росло и не убывало (-0,4\%), что отличает местные тенденции от таковых в Рязанской области.

\section{МИГРАЦИИ ТАТАР РЯЗАНСКОЙ ОБЛАСТИ: НАПРАВЛЕННОСТЬ, ХРОНОЛОГИЧЕСКИЕ РАМКИ}

В данной части исследования автор постарается дать по возможности детальную картину миграций татар с территории современной Рязанской области, указать основные направления, выявить причины миграций, их масштаб и последствия.

Из ряда научных публикаций известно, что некоторые этнотерриториальные группы татар имеют устойчивые связи «село» или «группа сел»- крупный город. Из наиболее характерных примеров таких связей можно привести связь татар Нижегородской области с Москвой и связь татар северо-запада Мордовии (темниковская группа) с Ленинградом/Санкт-Петербургом. Так, по данным Н.С. Гончаровой, в 1989 г. в Москве из числа татар, родившихся вне пределов города, 47\% (32,7 тыс. человек) родилось в Горьковской (Нижегородской) области [Гончарова 2003: 146]. По данным Г.В. Старовойтовой, 38,2\% мигрантов из числа татар прибыло в Ленинград из сел Мордовской АССР и Пензенской области. Г.В. Старовойтова объясняет это «устойчивостью раз сложившихся корреспонденций», т.е. «лучшей информированностью потенциальных мигрантов о том, что может дать им переселение, с другой - более легкого устройства на новом месте, возможности воспользоваться помощью земляков или родственников» [Старовойтова 1987: 57-58]. Логично предположить, что подобного рода связи могли сложиться и для татар Рязанской области.

\section{Анализ нарративных источников}

Согласно данным, представленным в ряде научных публикаций, а также публицистических статей о татарских селах Рязанской области, к основным направлениям миграции татар с территории региона в начале-середине XX в. можно отнести крупные города (Москва, Санкт-Петербург/Ленинград, Казань), крупнейшие промышленные районы (Донбасс, Баку) и, в наибольшей степени, регионы Средней Азии. Весьма интересным является также факт основания татарами-выходцами с территории современной Рязанской области села Куликовы Копани в Ставропольском крае, подтверждаемый рядом документов и нарративных источников. Вместе с тем местом притяжения наибольшего числа мигрантов из татарских сел Рязанской области стали именно регионы Средней Азии, в частности Узбекская ССР. 
Связи татар Рязанской области со Средней Азией стали налаживаться еще до революции, и были, судя по всему, основаны на торгово-коммерческом взаимодействии. В одной из татарских газет 1914 г. приводится следующий отрывок о крупнейшем татарскомишарском селе региона Азеево (ныне Ермишинского района): «Мусульмане Азеево богаты. Среди них даже есть несколько миллионеров. Основная торговля - с Бухарой. Поэтому их называют «бухарцы». Они прибрали к рукам все выгодные дела в Бухаре. Каракуль, кожа, пахта - всем этим занимаются азеевцы. Известные торговцы каракулем в Москве - тоже из Азеева» ${ }^{5}$. В энциклопедическом словаре «Ислам в центральноевропейской части России» про это же село говорится: «Подобно касимовским татарам, значительная часть жителей Азеево занималась обработкой и продажей меха (особенно каракуля), шелка из Средней Азии. Многие выходцы из Азеево уезжали в Андижан, Наманган, Бухару, Ташкент, Коканд, Самарканд, Хиву, а также в Москву, Санкт-Петербург, Оренбург, Петропавловск, Одессу. Они служили приемщиками хлопка, приказчиками. Со временем многие открывали собственное дело и торговали каракулем, хлопком, шелком, сухофруктами. С кон. 1920-х до конца 1940-х гг. продолжалась массовая миграция жителей Азеево в различные города Ср. Азии, а также в Москву» [Ислам... 2009: 11-13]. В этом же издании приводятся следующие сведения о селе Бастаново Сасовского района и ряде близлежащих татарских сел и деревень по реке Цна: «В начале 2000-х гг., по данным автора статьи (М.А. Сафаров, Д.З. Хайретдинов), относительно большим татарским селом остается только Бастаново, где увеличение населения произошло не только за счет естественного прироста, но и благодаря прибывшим на родину татарам из Средней Азии» [Ислам... 2009: 296]. «Сегодня вернувшиеся из Узбекистана бастановцы принимают наиболее активное участие в возрождении религиозной жизни в селе...» [Ислам... 2009: 38]. «Помимо возрождения религиозной жизни, был решен и ряд др. актуальных проблем. Среди них - в целом успешная адаптация татар, чьи предки или они сами выехали в Среднюю Азию и ныне вернулись на родину. Большинство этих людей имеют высшее образование, обладают высокой квалификацией, большую часть жизни прожили в городах, однако им удалось найти достойную работу в провинции. Характерно, что выходцы из Средней Азии принимали активное участие в возрождении мусульманских общин (например, в селе Бастаново)» [Ислам... 2009: 296].

В различных историко-краеведческих и генеалогических изданиях встречаются и сведения нарративного характера о выселении жителей татарских сел Рязанской области в Среднюю Азию в период коллективизации. Так, в монографии [Девликамов, Шарифуллина 2015] приводится следующий отрывок: «Житель г. Ташкента Акрем Ибрагимович Клеблеев написал нам, что его родители Клеблеев Ибрагим Азизович (годы жизни 1908-2003) и Клеблеева Магира Арифовна (годы жизни 1908-1988) родом из села Бастаново, откуда они уехали при «раскулачивании», бросив дом и солидное хозяйство, в Узбекистан, в г. Карши. У отца были братья Ислам и Фатех, сестры Кашифа и Фатиха, их дети сейчас живут в г. Ташкенте. ... По сообщению этого нашего информатора, очень много Клеблеевых и Клевлеевых, уроженцев села Бастаново, похоронены в г. Ташкенте на кладбище «Минор». 
Судя по некоторым публикациям, некоторую миграционную связь с регионами Средней Азии имели и касимовские татары, для которых, как уже говорилось, в отличие от татар-мишарей, была характерна более высокая мобильность, более активная вовлеченность в торговлю, промышленность, городской образ жизни и, как следствие, более широкий спектр возможных направлений миграций. «В советский период татарские села Касимовского района пришли в упадок: большинство населения выехало в Ленинград, Москву, города Средней Азии. В наше время постоянно проживающее здесь татарское население немногочисленно. Некоторые села стали полудачными, так как в них на летний период приезжают татары из Москвы и особенно из Санкт-Петербурга» [Ислам... 2009: 293].

Следует отметить, что миграция татарского населения в регионы Средней Азии, в частности в Узбекистан, в 1930-е-1950-е годы была общесоюзной тенденцией, включавшей в себя татар из самых разных регионов Центральной России, Поволжья и Урала. «Шестикратное увеличение численности татар в Казахстане и Средней Азии к концу 1950х гг. по сравнению с 1930-ми объяснялось несколькими причинами. Во-первых, в 1944 г. в Среднюю Азию (главным образом, в Узбекистан) были насильственно депортированы крымские татары ... Во-вторых, крупная группа татар переселилась в Казахстан в годы освоения целинных земель. Кроме того, происходил в целом отток татарского населения из ряда районов Европейской части страны в Среднюю Азию. В итоге этих процессов в 19701980-е годы в Казахстане и Средней Азии численность татар достигла более чем 1 млн (самая крупная часть татарской диаспоры). Однако между 1979 и 1989 г. численность татар в этом регионе выросла крайне незначительно (с 1154,1 до 1179,5 тыс. человек). Это связано с начавшимся возвращением крымских татар на историческую родину, а также с миграцией других групп татар за пределы Средней Азии» [Татары 2001: 155-158]. Последнее указанное в цитате обстоятельство, на наш взгляд, весьма хорошо коррелирует с выявленным трендом несколько неожиданного роста численности татар Рязанской области в 1970-2002 гг., особенно усилившимся в период с 1979 по 1989 г. В данном явлении почти наверняка присутствует фактор реэмиграции татар Рязанской области из регионов Средней Азии.

Упоминавшаяся ранее основная причина миграций татар Рязанской области в Узбекистан и прочие республики региона - раскулачивание - также в целом вписывается в общую канву социально-политических процессов в РСФСР, в значительной степени затронувших и татарское население. «В то же время с началом массовой коллективизации крестьянских хозяйств активизировалась миграция татарского населения в Среднюю Азию и Закавказье, особенно из Среднего Поволжья. Побросав свои хозяйства и земельные наделы, многие крестьяне ушли на различные стройки, нефтяные промыслы и шахты. Так, например, из сопредельных мест с Пензенской, Саратовской и Симбирской областями татары с семьями переселились на нефтяные промыслы Баку, из Татарстана - в республики Средней Азии (где они осели и образовали многочисленную татарскую диаспору). В результате активизации миграции среди сельского населения в 1930-1931 гг. начался массовый отток колхозного крестьянства из коллективных хозяйств. Так, вследствие массового выхода сельских жителей из колхозов количество обобществленных крестьянских хозяйств в Пензенской области сократилось до 25,2\%. Процесс миграции 
татарского населения в какой-то мере приостановил введение паспортной системы в сельской местности, которое жестко прикрепило бы их к колхозно-совхозной системе. В документах встречаются также данные о саботаже, поджогах и уничтожении колхозного имущества, убийстве активистов коллективной жизни и т.п. Таким образом, процесс коллективизации в татарских деревнях происходил крайне сложно. Процент кооперированного татарского крестьянства во многих местах компактного проживания татар Среднего Поволжья и Приуралья в середине 1930-х гг. был намного ниже аналогичных показателей по русским селам» [История татар... 2013: 300]. «Формирование национального состава [Узбекской ССР] в этот период (1926-1939) происходило под воздействием сложной экономической и социально-политической ситуации в бывшем Союзе. В социально-политическом плане это сопровождалось гражданской войной, повсеместными массовыми репрессиями. Репрессиям повергались относительно зажиточные слои сельского населения - «кулаки», научная и творческая интеллигенция, целые народы. В экономическом плане этот период характеризуется рядом экономических проблем, которые катастрофически сказались на многих регионах бывшего Союза. Bce это и ряд других катаклизмов в советском обществе стали причиной миграции населения из многих республик Советского Союза в Узбекистан и другие республики Центральной Азии. Миграция в этот регион осуществлялась в самых различных формах, но в основном преобладала принудительная, вынужденная и добровольно-стихийная миграция. ... Вынуждено было мигрировать из России, главным образом из ее мусульманских республик, и население, находившееся под угрозой раскулачивания и политических гонений» [Ата-Мирзаев и др. 2011: 96-97].

\section{Методика работы с ОБД «Мемориал»}

В условиях скудной статистической базы по местам выезда и въезда мигрантов, в особенности в период 1930-х гг., когда, предположительно, территорию Рязанской области покинула самая значительная волна мигрантов (учитывая причины переселений, следует также понимать, что почти наверняка многие покидали родные места неофициально), автор счел возможным обратиться к косвенным источниковым базам. Самым репрезентативным и надежным документальным источником по вопросу о направлениях миграций татар Рязанской области является Обобщенный банк данных (ОБД) «Мемориал» [ОБД... 2016], созданный по инициативе Минобороны РФ в 2007 г. и содержащий почти 17 млн цифровых копий документов о безвозвратных потерях и 20 млн именных записей о потерях Красной Армии в Великой Отечественной войне.

В указанных целях работа с ОБД «Мемориал» производится следующим образом. В разделе «Расширенный поиск» в строке «место рождения» необходимо ввести название того или иного населенного пункта (из списка М.А. Сафарова [Ислам... 2009: 293], Д.М. Исхакова [Этнотерриториальные группы... 2002: 98, 100, 105-106] и Ф.Л. Шарифуллиной [2004: 122]). В некоторых случаях, для более точного поиска и исключения из списка одноименных населенных пунктов из других регионов, нужно вводить уточняющие слова (например, «Бастаново» или «Бастаново Сасовский»). В ряде случаев, когда один и тот же населенный пункт может записываться по-разному, нужно ввести последовательно оба варианта (например, «Чернышево» и «Чернышово»), суммировав данные. В выдаваемых системой списках при нажатии на каждую запись можно увидеть сведения о месте призыва 
- по городским (ГВК) или районным (РВК) военным комиссариатам. Кроме того, в прилагающейся отсканированной версии официального документа в ряде случаев можно почерпнуть некоторые дополнительные сведения - место проживания ближайших родственников и др.

\section{Результаты анализа ОБД «Мемориал»}

Ниже приводится краткий перечень результатов по каждому населенному пункту.

Из 24 уроженцев села Бастаново Сасовского района были выбраны 23 человека с татарскими ФИО, из них 14 призваны Сасовским РВК, 5 - различными РВК/ГВК Узбекской CСР, 1 - Благодарненским РВК (Ставропольский край). Из 17 уроженцев села Тархань Каверинского (ныне Сасовского) района - 14 человек с татарскими ФИО, из них 7 призваны Каверинским РВК, 6 - различными РВК/ГВК Узбекской ССР, 1 - неизвестным РВК г. Владивосток, 3 - неизвестным ВК. Из 111 уроженцев села Алешино Сасовского района - 8 человек с татарскими ФИО, из них 3 призваны Сасовским РВК, 2 - РВК/ГВК Узбекской ССР, по 1 - РВК/ГВК Казахской ССР и Мурманской области, 1 - неизвестным ВК. Из 153 уроженцев сел Малый и Большой Студенец Каверинского (ныне Сасовского) района - 9 человек с татарскими ФИО, из них 4 призваны Каверинским РВК, по 1 - в г. Москва и Сталинградской области, 3 - неизвестными ВК. Из 136 уроженцев села Азеево Ермишинского района - 117 человек с татарскими ФИО, из них 49 призваны различными РВК Рязанской области, 34 - РВК/ГВК Узбекской ССР, 7 - РВК/ГВК Киргизской ССР, по 2 - РВК/ГВК Туркменской и Таджикской ССР, Татарской АССР, 22 - прочими или неизвестными ВК. Из 17 уроженцев села Верки Кадомского района - 10 человек с татарскими ФИО, из них различными ВК Рязанской области призвано 6 человек, ВК Узбекской ССР - 3, РВК г. Москвы - 1. Из 11 уроженцев села Чернышево (Чернышово) Кадомского района - 11 человек с татарскими ФИО, из них различными ВК Рязанской области призваны 4 человека, Киргизской ССР - 2, Узбекской, Украинской ССР и г. Ленинграда - по 1, неизвестными ВК - 2. Из 24 уроженцев села Иванково Ермишинского района - 15 человек с татарскими ФИО, из них различными ВК Рязанской области призваны 7, ВК г. Москвы - 3, Узбекской ССР - 2, Горьковской области - 1, неизвестными ВК - 2. Из 5 уроженцев села Молочная Гора Кадомского района - 1 человек с татарской ФИО, призван в Узбекской ССР.

Татарские села Касимовского района. В селе Толстиково выбраны 9 человек из 14 с татарскими ФИО, из них 8 призваны Касимовским РВК, 1 - Тюменским (?) РВК. В селе Мунтово - 9 из 10 человек с татарскими ФИО, из них 8 призваны Касимовским РВК, 1 РВК г. Ленинграда. В селе Четаево - 0 из 22 человек с татарскими ФИО. В селе Барамыково (Баромыково) - 1 из 15 человек с татарскими ФИО, призван РВК Ленинградской области. В селе Собакино - 3 человека из 3с татарскими ФИО, все призваны Касимовским РВК. В селе Шилино - 12 человек из 13 с татарскими ФИО, из них 8 призваны Касимовским РВК, 1 - РВК г. Ташкент Узбекской ССР, 1 - Московской области, 2 - неизвестными РВК. В селе Коверское - 0 из 12 человек с татарскими ФИО. В селе Подлипки - 18 из 20 человек с татарскими ФИО, из них 12 призваны Касимовским РВК, 2 - ВК г. Ленинграда и Ленинградской области, 4 - прочими РВК/ГВК. В селе Болотце (Болотцы) выбраны 7 из 10 человек с татарскими ФИО, из них 3 призваны Касимовским РВК, 1 - ГВК г. Рязань, 2 - ВК 
г. Ленинграда и Ленинградской области, 1 - в г. Москве. В селе Торбаево (Тарбаево) - 17 из 23 человек с татарскими ФИО, из них 8 призваны Касимовским РВК, 4 - ВК г. Ленинграда и Ленинградской области, 5 - прочими или неизвестными ВК. В селе Царицыно (Царицино) - 9 из 12 человек с татарскими ФИО, из них 5 призваны Касимовским РВК, 1 РВК Архангельской области, 3 - прочими или неизвестными ВК.

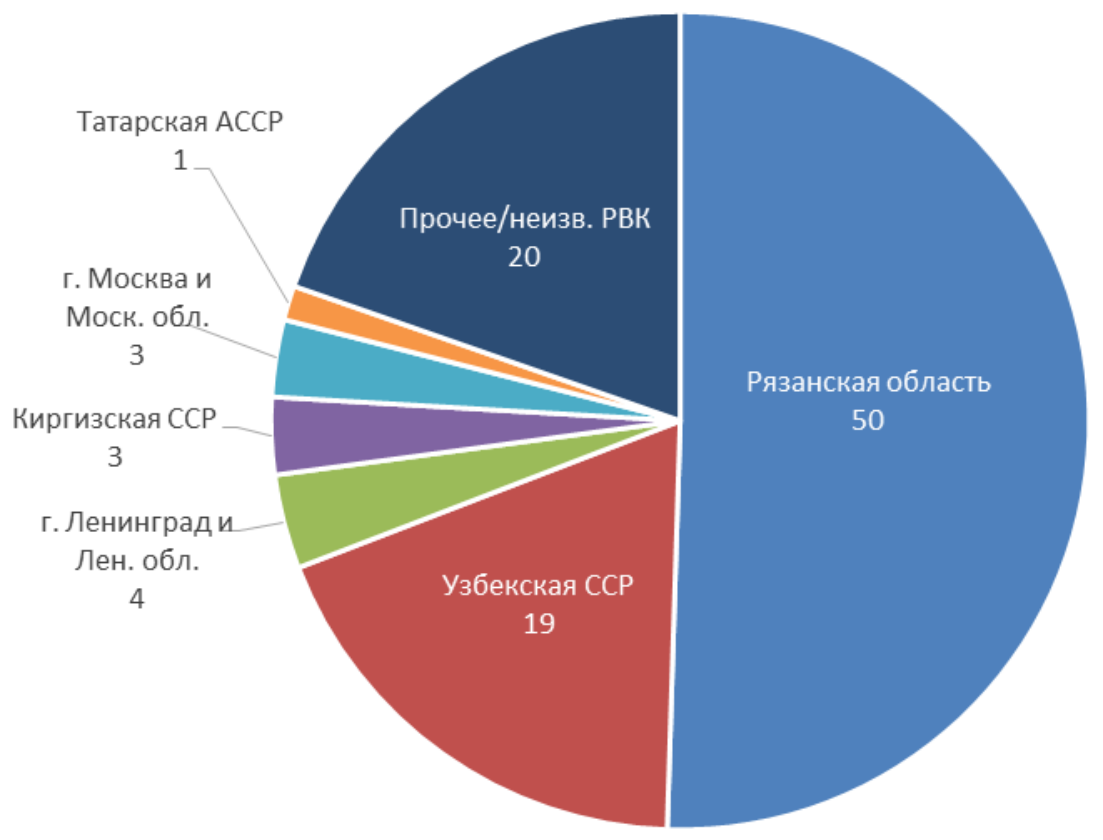

\section{Рисунок 3. Регионы призыва в РККА уроженцев татарских сел Рязанской области, \% от общего числа призванных}

При рассмотрении ситуации в целом по татарским селам Рязанской области (рисунок 3) вырисовывается следующая картина: около половины $(50,5 \%)$ их уроженцев, погибших в Великой Отечественной войне, было призвано в РККА в регионе рождения - в самой Рязанской области, в подавляющем большинстве - своими районными военными комиссариатами. Иными словами, эта половина представляет собой не уехавших, оставшихся в родных селах. На втором месте с явным отрывом идет Узбекская ССР: отсюда в годы Великой Отечественной войны было призвано 18,7\% уроженцев татарских сел Рязанской области. Всего же на республики Средней Азии приходится 23\%. 3,7\% приходится на Ленинград и Ленинградскую область, 3\% - на Москву и Подмосковье. Учитывая тот факт, что почти половина покинувших Рязанскую область уроженцев татарских сел призваны в Узбекской ССР и прочих республиках Средней Азии, можно считать как минимум доказанной важнейшую роль данного региона в миграционной структуре и связях татар Рязанской области, и прежде четко прослеживавшуюся по нарративным материалам и в ряде публицистических источников. 


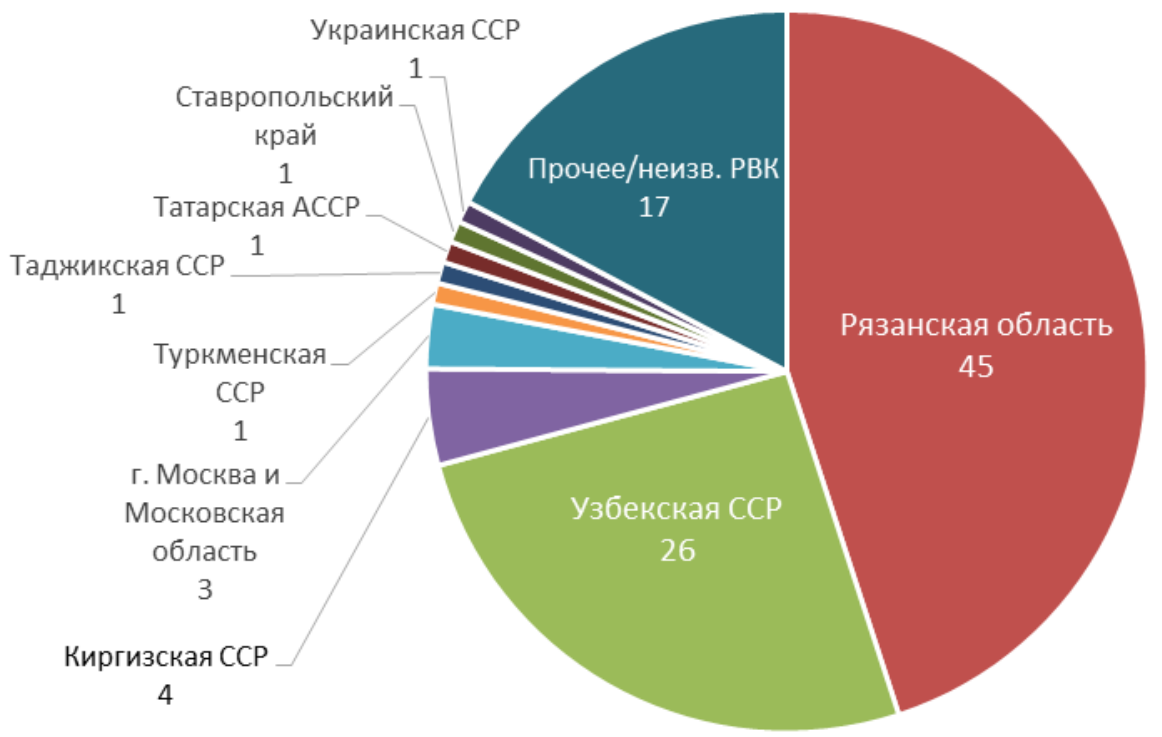

\section{Рисунок 4. Регионы призыва в РККА уроженцев татарско-мишарских сел Рязанской области, \% от общего числа призванных}

При рассмотрении отдельно татарско-мишарских сел области (Ермишинский, Кадомский, Сасовский районы; рисунок 4) доля Узбекской ССР, равно как и доля всех республик Средней Азии, увеличивается еще более, достигая 25,8 и 32\% соответственно. Параллельно резко, почти до нуля, уменьшается доля Ленинграда и Ленинградской области, доля Москвы и Подмосковья остается почти неизменной. Важно отметить, что при отдельном рассмотрении татарско-мишарских сел уменьшается доля самой Рязанской области - до $45 \%$, что говорит о более активных миграционных процессах в их среде в целом.

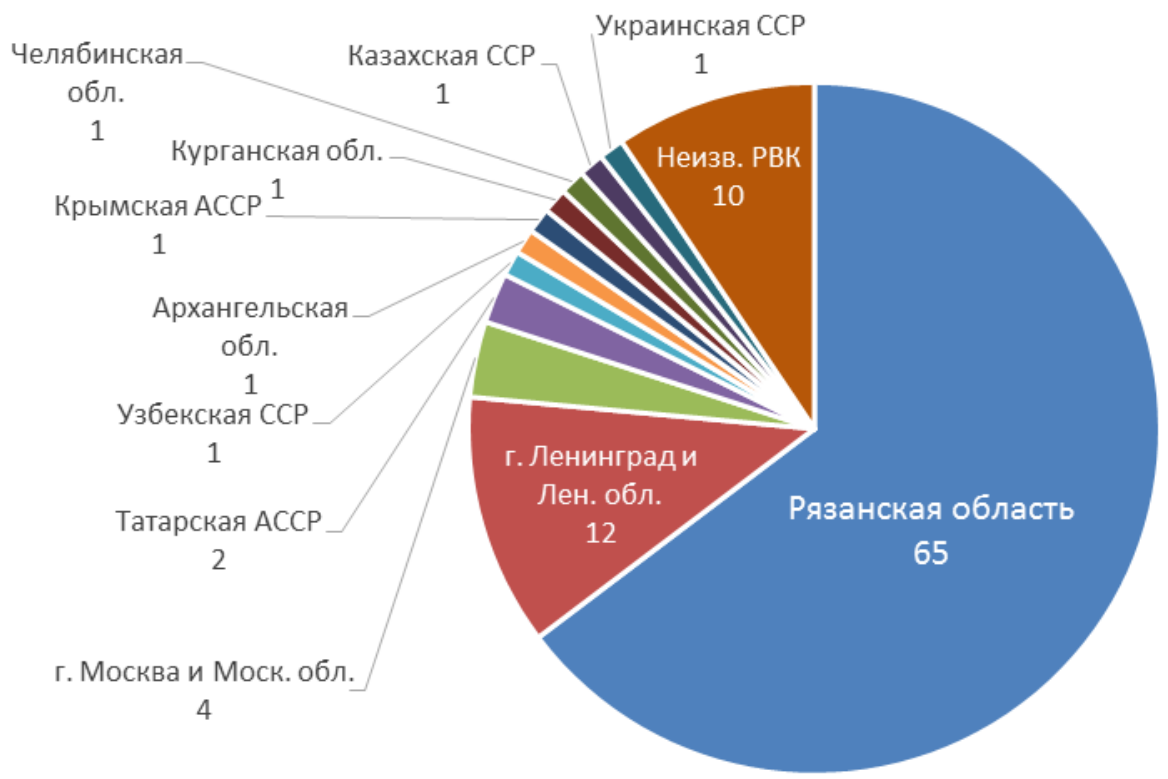

Рисунок 5. Регионы призыва в РККА уроженцев касимовско-татарских сел Рязанской области, \% от общего числа призванных 
При отдельном рассмотрении касимовских татар (Касимовский район; рисунок 5) бросается в глаза резкое увеличение доли самой Рязанской области (до 64,8\%), что говорит о пониженной миграционной активности на фоне татарско-мишарских сел региона. Резко падает роль республик Средней Азии при одновременном (до 11,8\%) росте доли Ленинграда и Ленинградской области, которые выходят на второе место, на третьем (3,5\%) - Москва и Подмосковье.

О том, что связи татар Рязанской области со Средней Азией не носят случайного характера, свидетельствует и тот факт, что во многих случаях в оригиналах документов, представленных в ОБД «Мемориал», присутствуют данные о родственниках, проживающих в различных городах Узбекской, Киргизской, Туркменской ССР и др., иными словами, призванные в РККА из этих республик уроженцы татарских сел проживали в них не одни, а вместе с семьями. По этим же данным можно судить, что татары - выходцы из Рязанской области селились преимущественно в городах (Ташкент, Самарканд, Бухара, Наманган, Фергана, Андижан, Ургенч и др.), а не в сельской местности Средней Азии.

Учитывая, что годы рождения большинства призывников - уроженцев татарских сел Рязанской области находятся в диапазоне с 1900 по 1925 г., можно предположить, что пик миграции пришелся на 1920-е - 1930-е годы, что подтверждает данные нарративных источников.

\section{Выводы}

Основные выводы, сделанные по итогам настоящего исследования.

1. Начиная с 1920-х годов наблюдается сначала падение численности татарского населения Рязанской области до 1970 г., рост в 1970-2002 гг. и последующее повторное падение с 2002 г. При этом указанная динамика падения не коррелирует с таковой в соседних регионах с татарским населением и в России в целом, обладая собственными характерными чертами, в частности периодом роста с 1970 по 2002 г.

2. Средняя Азия (и особенно Узбекистан) играет большую роль в миграционных потоках татарских сел Рязанской области. Данный регион является устойчивым ядром рязанскотатарской диаспоры, наподобие того, какую роль играет Москва для нижегородских татар и Ленинград/Санкт-Петербург для татар северо-запада Мордовии. При этом данный вывод в большей степени характерен для татарско-мишарских сел области, расположенных в Ермишинском, Кадомском и Сасовском районах.

3. Причинами миграций, учитывая выводы, полученные при анализе статистических материалов и сопоставлении их с имеющимися научными исследованиями, стали в первую очередь «чрезвычайные меры» в советской деревне конца 1920-х годов, коллективизация 1929-1933 гг., голод начала 1930-х годов, а также в определенной мере и репрессии по религиозному признаку.

4. Фактор роста татарского населения Рязанской области в 1970-2002 гг., особенно заметный на рубеже 1980-х - 1990-х годов, с большой долей вероятности может быть объяснен реиммиграционными потоками из республик Средней Азии в связи с общим ухудшением социально-экономической обстановки в этом регионе и 
дезинтеграционными процессами. Повторное падение численности татар Рязанской области, наблюдаемое с 2002 г., может быть объяснено иссяканием указанного реиммиграционного потока с последующим возвращением к общей тенденции естественной убыли населения

5. Как в отношении динамики роста/убыли численности населения в ареалах проживания, так и в отношении направленности миграционных потоков две основные этнотерриториальные группы татар Рязанской области (касимовские татары и татарымишари) имеют четкие особенности, отличающие их друг от друга. Для касимовских татар характерна прослеживающаяся еще с XIX в. естественная убыль, меньшая тенденция к выезду на жительство за пределы региона (соответственно, сокращение численности за счет более активных ассимиляционных процессов). Среди выезжавших в другие регионы в начале - середине XX в. значительная доля приходилась на крупные центры: Москву и особенно Ленинград и пригороды. Для татар-мишарей Рязанской области более характерен стремительный рост численности в начале XX в., большая тенденция к выезду на жительство в другие регионы, среди которых особое место занимает Средняя Азия и особенно Узбекистан. Данные регионы были освоены отдельными представителями торгового сословия рязанских татар еще на рубеже XIX$\mathrm{XX}$ вв., и впоследствии массовая миграция в данный регион легла на подготовленную почву.

На взгляд автора, имеются широкие перспективы дальнейшего изучения татар Рязанской области и других областей Центральной России сразу по нескольким направлениям, в частности в исследованиях процессов ассимиляции, смены/сохранения национальной и религиозной идентичности, а также демографического перехода и обусловливающих его факторов

\section{БЛАГОДАРНОСТИ}

Автор выражает признательность С.Г. Сафронову и М.С. Савоскул за ценные рекомендации при сборе материала и написании статьи.

\section{СПИСОК СОКРАЩЕНИЙ}

ОБД - Обобщенная база данных

ГВК - Городской военный комиссариат

РВК - Районный военный комиссариат

ВК - Военный комиссариат 


\section{ЛИТЕРАТУРА}

Ата-Мирзаев О.Б., В.Л. Гентшке, Р.Х. Муртазаева (2011). Узбекистан многонациональный: историко-демографический аспект. Ташкент: Янги аср авлоди. $251 \mathrm{c}$.

Гончарова Н.С. (2003). Татары в Москве: Опыт историко-статистического исследования: дис. ... канд. ист. наук. М: Институт этнологии и антропологии им. Н.Н. МиклухоМаклая РАН.

Девликамов А.А., Ф.Л. Шарифуллина (2015). Очерки по истории и культуре села Бастаново. Шацк: Шацкая типография. 359 с.

Переписи населения Российской Империи, СССР, 15 новых независимых государств (2016) // Демоскоп Weekly. №695-696. URL: http://demoscope.ru/weekly/pril.php (дата обращения: 10.07.2016).

Ислам в центрально-европейской части России (2009). Энциклопедический словарь / Под ред. Д.З. Хайретдинова. М.: Медина. 403 с.

История татар с древнейших времен (2013). Т.7. Татары и Татарстан в XX - начале XXI в. / Под ред. Р.С. Хакимова, Р.Р. Салихова. Казань: Институт истории Академии наук Республики Татарстан. 1003 с.

Исхаков Д.М. (1993). Этнографические группы татар Волго-Уральского региона: Принципы выделения, формирование, расселение и демография. Казань: ИЯЛИ. 172 с.

Макаров Д.В. (2012). Дорогами ислама Центральной России. М.: Марджани. 205 с.

Мухамедова Р.Г. (1972). Татары-мишари: Историко-этнографическое исследование. М.: Наука. 248 с.

ОБД «Мемориал» (2016). Обобщенный банк данных «Мемориал» о потерях Красной Армии в Великой Отечественной войне. Москва: Министерство обороны PФ. URL: https://www.obd-memorial.ru/html/advanced-search.htm (дата обращения: 10.07.2016).

Старовойтова Г.В. (1987). Этническая группа в современном советском городе. Л.: Наука. $174 \mathrm{c}$.

Татары (2001). Серия «Народы и культуры» / Под ред. Р.К. Уразмановой, С.В. Чешко. М.: Наука. 582 с.

Шарифуллина Ф.Л. (2004). Касимовские татары: историко-этнографическое исследование традиционной народной культуры середины XIX - начала XX в. // Рязанский этнографический вестник. №33: 2-127.

Этнотерриториальные группы татар Поволжья и Урала и вопросы их формирования. Историко-этнографический атлас татарского народа (2002) / Под ред. Р.К. Уразмановой, Н.А. Халикова. Казань: Дом печати. 247 с. 


\title{
TATARS OF THE RYAZAN REGION IN THE XX CENTURY: GEOGRAPHY OF SETTLEMENT, POPULATION DYNAMICS, MIGRATION TRENDS
}

\section{RENAT TEMIRGALEEV}

\begin{abstract}
The article discusses various demographic and migration processes among the Tatars of the Ryazan region, consisting of two ethno-territorial groups - Kasimov Tatars and Mishar Tatars. The analysis of statistical data, narrative sources, and data from the "Memorial" database of the dead and missing in the Great Patriotic war, revealed a special and leading role of Central Asia (especially Uzbekistan) in migration patterns of the Tatars of the Ryazan region. It was found that the two main groups of Tatars in the Ryazan region - Kasimov Tatars and Mishar Tatars - have distinct features, clearly distinguishing them from each other both in terms of the dynamics of growth/decline of population in their habitats of residence, and in the direction of their migration flows. An original method of identifying directions of migration flows was also developed based on the "Memorial" database, which contains documents on the irretrievable losses of the Red Army in World War II by the criterion of "place of birth - place of recruiting".
\end{abstract}

Key words: Central Asia, Demographics, Kasimov Tatars, "Memorial", migration, Mishar Tatars, Ryazan region, Tatars.

RENAT F. TEMirgaleEv (renattemirgaleev@yandex.ru), Lomonosov Moscow State University, Russia.

DATE RECEIVED: JUNE 2016.

\section{REFERENCES}

Ata-Mirzayev O.B., V.L. Gentshke, R.H. Murtazayeva (2011). Uzbekistan mnogonatsional'nyy: istoriko-demograficheskiy aspekt [Uzbekistan multinational: Historical and demographic aspect]. Tashkent: Yangi asr avlodi . $261 \mathrm{p}$.

Devlikamov A.A., F. L. Sharifullina (2015). Ocherki po istorii i kul'ture sela Bastanovo [Essays on the history and culture of the Bastanovo village]. Shatsk: Shatskaya tipografiya. $359 \mathrm{p}$.

Etnoterritorial'nye gruppy tatar Povolzh'ya i Urala i voprosy ikh formirovaniya. Istorikoetnograficheskiy atlas tatarskogo naroda [Ethno-territorial groups of Tatars of the Volga region and the Urals and the issues of their formation. Historical-ethnographic atlas of the Tatar people] (2002) / R.K. Urazmanova, N.A. Khalikov, eds. Kazan: Dom pechati. 247 p.

Goncharova N.S. (2003). Tatary v Moskve: Opyt istoriko-statisticheskogo issledovaniya: dis. ... kand. ist. nauk [Tatars in Moscow: Experience of the historical-statistical research: $\mathrm{PhD}$ Thesis]. Moscow: Institut etnologii i antropologii im. N.N. Miklukho-Maklaya RAN.

Iskhakov D.M. (1993). Etnograficheskie gruppy tatar Volgo-Ural'skogo regiona: Printsipy vydeleniya, formirovanie, rasselenie i demografiya [Ethnic groups of Tatars of the VolgaUral region: Principles of selection, formation, settlement, and demography]. Kazan: IYaLI. $172 \mathrm{p}$.

Islam v tsentral'no-evropeyskoy chasti Rossii [Islam in the Central European part of Russia] (2009) Entsiklopedicheskiy slovar' [Encyclopedic Dictionary] / D.Z. Khairetdinov, ed. Moscow: Medina. 403 p.

Istoriya tatar s drevneyshikh vremen [History of Tatars since antiquity] (2013). T.7. Tatary $\mathrm{i}$ Tatarstan v XX - nachale XXI v. [Vol.7. Tatars and Tatarstan in the XX - beginning of XXI 
century] / R.S Khakimov, R.R.Salikhov, eds. Kazan: Institut istorii Akademii nauk Respubliki Tatarstan. 1003 p.

Makarov D.V. (2012). Dorogami islama Tsentral'noy Rossii [Roads of Islam in Central Russia]. Moscow: Mardzhani. 205 p.

Mukhamedova R.G. (1972). Tatary-mishari: Istoriko-etnograficheskoe issledovanie [Mishar Tatars: Historical and ethnographic research]. Moscow: Nauka. 248 p.

OBD «Memorial» [«Memorial» database] (2016). Obobshchennyy bank dannykh «Memorial»o poteryakh Krasnoy Armii v Velikoy Otechestvennoy voyne [Generalized data bank about the losses of the Red Army in World War II «Memorial]. Moscow: Ministerstvo oborony RF. URL: https://www.obd-memorial.ru/html/advanced-search.htm (accessed: 10.07.2016).

Perepisi naseleniya Rossiyskoy Imperii, SSSR, 15 novykh nezavisimykh gosudarstv [Censuses of the Russian Empire, the Soviet Union, 15 new independent states] (2016) // Demoscope Weekly. №695-696. URL: http://demoscope.ru/weekly/pril.php (accessed: 10.07.2016).

Sharifullina F.L. (2004). Kasimovskie tatary: istoriko-etnograficheskoe issledovanie traditsionnoy narodnoy kul'tury serediny XIX - nachala XX v. [Kasimov Tatars: Historical and ethnographic research of traditional folk culture of the mid XIX - early XX century] // Ryazanskiy etnograficheskiy vestnik. 33: 2-127.

Starovoytova G.V. (1987). Etnicheskaya gruppa v sovremennom sovetskom gorode [Ethnic group in the modern Soviet city]. Leningrad: Nauka. 174 p.

Tatary [Tatars] (2001). Seriya "Narody i kul'tury" ["Peoples and Cultures" series] / R.K. Urazmanova, S.V. Cheshko, eds]. Moscow: Nauka. 582 p. 